This is the final peer-reviewed accepted manuscript of:

Caetano Luiz Beber, Ludwig Theuvsen, Verena Otter

Organizational structures and the evolution of dairy cooperatives in Southern Brazil: A life cycle analysis

which has been published in final form in Journal of Co-operative Organization and Management, Volume 6, Issue 2, December 2018, Pages 64-77

The final published version is available online at:

https://doi.org/10.1016/i.jcom.2018.06.003

(C) 2018 Elsevier. This manuscript version is made available under the Creative Commons Attribution-NonCommercial-NoDerivs (CC BY-NC-ND) 4.0 International License (http://creativecommons.org/licenses/by-nc-nd/4.0/) 


\title{
Organizational structures and the evolution of dairy cooperatives in Southern Brazil: A life cycle analysis
}

\author{
Caetano Luiz Beber*, Ludwig Theuvsen, Verena Otter \\ Department of Agricultural Economics and Rural Development, University of Goettingen, Platz der Göttinger Sieben 5, 37073, Göttingen, Germany
}

\section{A R T I C L E I N F O}

JEL classifications:

Q13

Q18

Keywords:

Dairy cooperative

Small farms

Life cycle analysis, dairy sector

\begin{abstract}
A B S T R A C T
Mesorregião Grande Fronteira do Mercosul (GFM) in southern Brazil is the country's largest dairy production area. This region has the highest concentration of dairy cooperatives of small and medium-sized producers in the country. Nevertheless, the traditional policies and practices of Brazilian cooperatives no longer align with market realities and the exclusion of less efficient cooperatives from the market affects many small family farms. This study about the development of dairy cooperatives located in the GFM aims to identify these cooperatives' vulnerabilities and improvements that can increase their competitiveness. Using Cook's (1995) life cycle approach, we describe the evolution of cooperatives in the dairy industry in this region. The results indicate the necessity of new designs for GFM dairy cooperatives' business models and strategies in order to disconnect them from government aid. Measures to enhance their market competitiveness are necessary to promote self-sufficiency in this growing sector and maintain family farms' continued existence.
\end{abstract}

\section{Introduction}

More exigent consumers and more competition lead to changes in agri-food chains. The major change is the shift from production orientation to producers adopting a market focused strategy, driven by an increasing consumer demand for greater quality and a larger variety of products. However, some less efficient traditional cooperatives face difficulties in securing the necessary risk capital to invest in marketing strategies and risk being excluded from the market (Chaddad \& Cook, 2004). This issue is extremely relevant for dairy cooperatives and the small family farms associated with them in the Mesorregião Grande Fronteira do Mercosul (GFM).

GFM, located in southern Brazil, ${ }^{1}$ is the largest dairy production area in the country. Its production is based on family farms and cooperatives and, as the dairy sector becomes increasingly competitive, it is growing faster than in all the other regions in the country (Anschau, 2011). This growth is driven by increasing domestic demand for dairy products since, over the last 10 years, middle-class consumers have grown from $38 \%$ to $56 \%$ of the population and today account for more than 119 million people. Nevertheless, the aggressive process of industrial concentration in the hands of large investor-owned firms (IOFs), both national and multinational, put the fragile organization of regional cooperatives at risk. The possibility of market saturation and difficulties regarding export also threaten both the cooperatives in the GFM and the many small family farms linked to them for which dairy provides the main source of income (Medeiros \& Padilha, 2015). The southern region of Brazil had 606,000 farmers actively involved in dairy in 1996; only 412,000 were still active in 2006-a decline of $32 \%$ (IBGE, 1996, 2006). However, production increased by $28 \%$ over the same period. In Brazil, there are about 6.8 thousand cooperatives as compared with 6 million IOFs. Only $7 \%$ to $8 \%$ of Brazil's total national GDP is generated by these cooperatives, of which $90 \%$ are agricultural (OCB, 2012).

Despite its present importance, milk has always been a secondary source of income within GFM farms' business models whilst other products, like poultry, pork and cereals, have been the major crops since the mid-1950 s (Escher, 2011a). Specialization in the latter sectors has led to investment in specific assets, vertical integration and, in consequence, the exclusion of many small farmers who entered dairy production in order to subsist (Ferrari, Luiz, Antonio, Marcos Testa, \& Luiz Silvestro, 2005). As a result, farmers formed dairy cooperatives to counter market failures hence following a defensive strategy against market risks. In this regard, dairy cooperatives in the GFM have played an important role in maintaining the survival of family farms since they, in contrast to other companies, provide an important service for small producers: the purchase and collection of products even in the

\footnotetext{
* Corresponding author.

E-mail address: cbeber@uni-goettingen.de (C.L. Beber).

${ }^{1}$ The South of Brazil comprises three states: Paraná, Santa Catarina and Rio Grande do Sul.
} 
most remote regions (de Souza, 2014). However, since the mid-1990s, the dairy industry has been growing and has followed the same method of specialization and exclusion as other agribusiness sub-sectors. Despite the significant progress made with the organization of dairy cooperatives, less efficient traditional cooperatives face difficulties in obtaining the risk capital necessary to invest (Schubert \& Niederle, 2011) and so increase competitiveness. This is due to the fact that some of the traditional policies and practices adopted by Brazilian cooperatives no longer seem to align with market realities (Chaddad, 2007a, 2007b). Due to the great importance of cooperatives for the dairy sector, especially for small producers, their exit from the market could generate major financial problems for thousands of farmers and their families. However, the evolution of such cooperatives and their failure have never been analyzed historically and especially not by the means of a life cycle analysis, which places special attention on the internal and external issues that, over time, have changed these Brazilian institutions. This paper also focuses on the evolution of the politico-economic scenario that has played a major role in the competitiveness, resilience and decline of dairy cooperatives in the GFM.

This paper also analyzes in detail the historical development of GFM dairy cooperatives in order to identify the failures responsible for their poor performance. Using the life cycle approach developed by Cook (1995) as a framework for qualitative analysis, it examines the influences on the cooperatives' competitiveness, of failures in their organizational dynamics and of the institutional, political, and economic environment. Therefore, instead of focusing on one single cooperative as proposed by Cook (1995), this study provides a descriptive application of the life cycle approach for the entire sector of dairy cooperatives in this specific region. The sector as the unit of analysis was tested successfully by Chaddad (2007a). However, in his study the approach was applied at the national level, drawing conclusions on the general future viability of farmer cooperatives in the agricultural sectors of a globalized world. In our case we concentrate on a specific dairy production zone in order to derive concrete management and policy implications for improving future competitiveness as. These management implications are of great relevance for such interested parties as cooperatives' boards of directors. This paper also contributes to the academic literature by further developing Cook (1995) approach to cooperatives' life cycle analysis, testing it on a specific case and deriving an extension to the method. Furthermore, an examination of political implications should be of interest to political decision makers in Brazil, who hope to initiate institutional reforms providing special incentives such as support/consulting services and access to specific lines of credit for the dairy cooperatives in order to preserve family farms in the region under analysis.

The remainder of the paper is organized as follows: Section 2 presents the conceptual framework and Section 3 provides insights into the GFM dairy sector followed by an outline of the methodology in Section 4 also with an overview of the national cooperative system's structure. Section 5 presents the results and in Section 6 we close with a discussion of the results and our conclusions.

\section{Conceptual framework}

Based on former theories about the dynamics of a cooperative's evolution, Cook (1995) developed a five-step life cycle framework for cooperatives (LCC) (see Table 1). His aim was to understand the evolution of U.S. agricultural cooperatives better and within the politicoeconomic scenario, which had played a major role regarding their competitiveness, resilience or decline. This approach was further developed by Cook and Burress (2009) and has since been applied to cooperatives from various sectors in developing, transitional and industrialized countries. With regard to industrialized countries, Whitman (2011) described the LCC of a workers' cooperative in the United States in order to explore their motivation when starting the cooperative and learn about the stages of the cooperative's life cycle.
This study also sought to identify possible problems that can be encountered or avoided at each stage in the cooperative life cycle. Terfloth (2015) applied the LCC to understand the collapse of one of the largest and most influential consumer cooperatives in North America, the Berkeley Co-op. With regard to developing and transition countries, Chaddad (2007a) applied the LCC in his analysis of the Brazilian dairy industry, using the whole sector as the unit of analysis and not just one cooperative. Conclusions were then drawn on the future role of farmer cooperatives in an agricultural sector under the shadow of globalization. Wouterse and Francesconi (2016) assessed the organizational health of 253 cooperatives in three African countries, showing that the cooperatives' state evolves according to a life cycle, as Cook (1995) had suggested. In a similar study, Francesconi and Ruben (2008) assessed the collective marketing engagement of 200 cooperatives in Ethiopia. They compared cooperatives established by farmers as a voluntary initiative and those established by an external initiative (government or NGO). This study identified a different life cycle for each group. Cooperatives that grew from farmers' initiatives, having an economic justification for their establishment, proved to be more sustainable and able to readapt more easily during times of crisis. They followed the five stages of Cook's LCC. In contrast, cooperatives established by external initiatives more often formed, declined, and exited without showing the same LCC trend.

Ben-Ner (1988) analyzed the life cycle of worker-owned firms in market economies by comparing sectors in different industrialized countries, starting from the premise that such firms are formed during periods of crisis in a countercyclical dynamic. He stated that adverse economic conditions increase the advantages of worker-owned firms by raising the cost of adversarial relations in IOFs. This leads to an increase in the worker-owned firm's formation activity. Governments and other organizations may also encourage and foster the formation of such firms if they realize that they can constitute a comparatively inexpensive measure to combat unemployment. Changes in the environment, especially the regrowth of the economy and those firms' own growth, may gradually transform them into IOFs as they hire wage laborers and their members aspire to higher personal incomes in a firm reorganized as an IOF. However, this countercyclical pattern could also vary across countries and sectors. Pérotin (2006) came to the same conclusion in her empirical article examining the determinants of entry and exit among IOFs and worker cooperatives in France, a country with a long tradition in cooperative forms of business. In this case the creation of cooperatives is related to the rise of unemployment, lowering the opportunity cost of creating a firm and raising income risks associated with employment in conventional firms. On the other hand, Staber (1993) found, when measuring the founding and failure rates of worker cooperatives in Maritime Canada, that such firms enter and exit the market independent of changes in general economic conditions.

Our study builds on these previous studies by using the LCC approach and its five recurring steps as the underlying approach for the qualitative in-depth analysis.

The life cycle approach starts by identifying the economic justification for forming the cooperative. Cooperatives are formed mostly as a defensive strategy against market failure and price slumps induced by oversupply (Cook, 1995), in turn providing economic benefits to members due to their higher efficiency in comparison to IOFs (Hendrikse \& Feng, 2013).

In the second stage, principles, rules and policies are developed defining the institutional framework for cooperatives' establishment and day-to-day operation. At this stage sector- and country-specific institutional environments influence the development of cooperatives and should be taken into consideration. This new environment generates costs that need to be compensated by the benefits of collective action through cooperatives in order to survive this stage of development economically (Chaddad, 2007a). Cook (1995) argues that cooperatives created due to oversupply do not generally persist beyond this stage. 
Table 1

Cook's Life Cycle approach.

Adapted from Chaddad (2007a) and Cook (1995).

\begin{tabular}{|c|c|}
\hline Stage & Description \\
\hline 1 Economic justification & Cooperatives are formed to protect the value of farmers' assets in situations of oversupply and/or market failure. \\
\hline 2 Organizational design & $\begin{array}{l}\text { The institutional environment (e.g., incorporation statutes, tax laws) sets rules (and therefore costs) for cooperatives' formation and } \\
\text { functioning that must be compensated for by the benefits of collective action to ensure the survival of the cooperatives. }\end{array}$ \\
\hline 3 Growth and consequences & $\begin{array}{l}\text { The growth of cooperatives leads to increasing awareness of internal transaction costs, which include free-rider, portfolio, horizon, } \\
\text { control, and influence-cost problems. }\end{array}$ \\
\hline 4 Crisis and recognition of conflicts & $\begin{array}{l}\text { Challenges to management of cooperatives appear as a result of pressures from the competitive environment and internal transaction } \\
\text { costs. Cooperative leaders are confronted with three strategic options: exit, minor changes to the traditional structure, and shift to a new } \\
\text { model. }\end{array}$ \\
\hline 5 Restructuring & Cooperative leaders choose between strategic options, and a new life cycle begins. \\
\hline
\end{tabular}

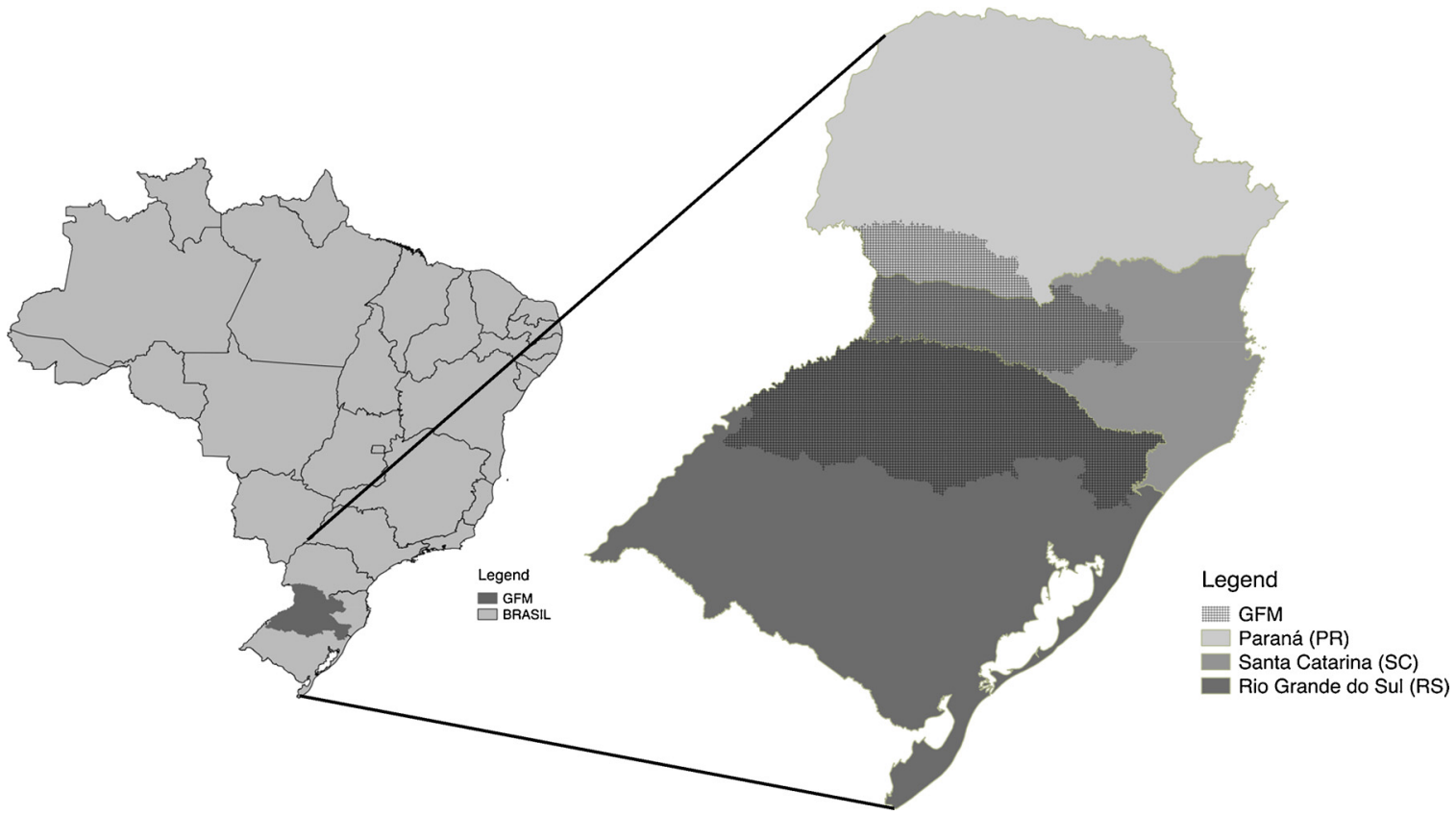

Fig. 1. Map of Brazil with southern Brazil and GFM highlighted (left). The three states of southern Brazil and GFM shaded (right). Source: Authors' elaboration based on data from IBGE (2014).

Cooperatives that survive the second stage enter into a growth phase (third stage). This growth leads to their being perceived as competitors by IOFs, which adapt to the cooperative competition by increasing their payments in order to ensure supply. On the other hand, cooperative members realize that the short-run costs of transacting with a cooperative are high. These transaction costs originate from the ownership structure of traditional cooperatives (Chaddad \& Cook, 2004). Cook (1995) describes them as the vaguely-defined property rights (VDPR) constraints, which include the free-rider, portfolio, horizon, control, and influence-cost problems.

The fourth stage is crisis and recognition of conflicts. At this point, cooperative leaders face difficulties in managing their cooperatives due to pressures from the competitive environment. As a result, in the fifth stage of the life cycle, managers must decide on one of the following three strategic options (Cook \& Iliopoulos, 1998; Cook, 1995; Iliopoulos \& Cook, 2013):

Option 1: Exit through either liquidation or conversion into an IOF. Low performance cooperatives tend to liquidate or merge with other cooperatives, whilst high performance cooperatives tend to convert into IOFs. Mergers and acquisitions are included in this strategy.

Option 2: Continue. Undercapitalized cooperatives appear to choose one of two options at this stage: the first option is to seek outside equity capital without restructuring as an IOF. This is done through strategic alliances (with publicly held subsidiaries, joint ventures, or limited liability companies). The second option is to pursue a proportionality strategy of internally generated capital. In this case, financial responsibility is shared on a proportional basis (Cook \& Iliopoulos, 1998), which results in policies and strategies such as base capital plans, proportional voting, narrowing product scopes, pooling on a business unit basis and capital acquisition on a business unit basis (Cook, 1995).

Option 3: Shifting to a New Generation Cooperative. This cooperative structure attempts to ameliorate the five VDPR issues. It is achieved by developing asset appreciation mechanisms, increasing share liquidity by creating delivery rights, base equity capital plans and membership policies to eliminate external free riders aligning residual rights of control with residual claims within the cooperative organization (Cook \& Iliopoulos, 1998).

\section{The dairy sector in "Grande Fronteira do Mercosul" (GFM)}

In 2007, the Brazilian Ministry of National Integration proposed the establishment of 13 mesoregions based on historical, cultural, social, and political identity. These regions have similar institutions, social problems and economic dynamics, which have been used in the application of various development programs and policies.

One of these is the "Mesorregião Grande Fronteira do Mercosul" (GFM), which comprises 415 municipalities in northwestern Rio Grande do Sul (NW-RS), Western Santa Catarina (W-SC), and southwestern Paraná (SW-PR) - the three states that comprise the southern 
region of Brazil with $139,200 \mathrm{~km}^{2}$ and 3.8 million inhabitants in total (Deves, Rambo, and Miguel 2008). Fig. 1 shows the exact location of GFM in the respective states in southern Brazil.

Nowadays, about $35 \%$ of the GFM population lives in rural areas, which is far above the countrywide average of $19 \%$. Correspondingly, small-scale farms predominate since $40 \%$ of farmers own less than 10 ha. The GFM comprises one quarter of the total area of southern Brazil but accounts for only one tenth of its GDP, mainly through agricultural production and agroindustry. In this respect, the most relevant products are cereals, pork, poultry, beef and dairy cattle, fruit, yerba mate and tobacco. The region has recently experienced a process of economic restructuring in response to the impact of globalization (MESOMERCOSUL, 2007). Dairy cows are present on nearly all family farms in southern Brazil. Until the $1910 \mathrm{~s}$ they generally had a subsistence role for the families. Soya beans, pork, poultry and tobacco were traditionally the main sources of farm income. Large agribusiness companies generally dominate these sectors and the historical as well as the economic instabilities in them promoted the exclusion of many family farmers, creating anti-corporate sentiments among them. Cooperatives $^{2}$ already installed in the region for other activities (soya bean, pork, poultry) adapted their plants to collect milk from farms in order to provide farmers with income and enable their continued existence in rural areas. More recently (since the $1970 \mathrm{~s}$ ) instability and displacement in the pork and poultry industries plus government incentives to reduce tobacco cropping have further enhanced the region's dairy sector (Escher, 2011a). Less concentrated and more competitive, dairy production has become an important business in the region. Many IOFs have been established and many new cooperatives have been created. The supply chain has become more structured and complex as production has increased.

The Brazilian milk production sector has experienced a rapid and significant growth since the $1990 \mathrm{~s}$ mainly driven by the dairy sector in the GFM (see Fig. 2). In 1992, for instance, the Brazilian milk production accounted for only 15.8 billion liters. By 2006, production quantities had increased to 25.4 billion liters of which $13.3 \%$ was produced in the GFM. In this region $60 \%$ of the farms produced milk as their main or secondary product in 2006 . That made a total of 182 thousand farms producing milk from 1.95 million cows in 371 municipalities (IBGE, 2017). According to the IBGE this milk generated US $\$ 396$ million in total in the same year, representing $9.2 \%$ of agricultural GDP and $2.7 \%$ of the total GDP in the GFM, which corresponds to on average US \$ 2000 per farm/year. In 2015, Brazil produced 35 billion liters of milk, of which GFM production alone accounted for roughly 18.5\% (6.46 billion liters) collected by 420 companies.

Marketing companies, generally IOFs, which are experienced

\footnotetext{
${ }^{2}$ A cooperative is defined in the Brazilian Federal Law 5764 of 1971 as a society with its own form, legal status, and civil status, which is not subject to bankruptcy, which has been established to provide services to members, and which distinguishes itself from other companies by the following characteristics: (I) voluntary membership, with an unlimited number of members, unless its growth makes it technically impossible to provide services; (II) variability of the capital represented by shares; (III) limiting the number of shares of capital for each member, but allowing the establishment of proportionality criteria if doing so is more suitable for the achievement of social objectives; (IV) inaccessibility of the capital shares to third parties outside the society; (V) uniqueness of vote, while allowing central cooperatives, federations, and confederations of cooperatives, with the exception of those of credit activities, to opt for the principle of proportionality; (VI) quorum for the operation and resolution of the general assembly based on the number of members and not on capital; (VII) return of the net profits of the year in proportion to the operations carried out by the member, unless otherwise decided by the general assembly; (VIII) indivisibility of financial reserve and of technical assistance, educational, and social reserves; (IX) political neutrality and religious, social, and racial nondiscrimination; $(\mathrm{X})$ provision of assistance to members, and, when determined in the statutes, to employees of the cooperative; (XI) associates' admission area limited to facilities for meeting, control, operations, and services.
}

competitors on the commercialization side, are operating in the prominent GFM area and competing on the production side as well. Growth in production, movement towards concentration and professionalization along the entire value chain are increasing competitive pressure in the sector. Cooperatives, which are highly dependent on good market prices for spot milk and government support, are having serious problems maintaining sustainable activity. They are also not acting fast enough to adapt to this competitive environment.

In this article we investigate the historical development of GFM dairy cooperatives and identify the main failures responsible for their current poor performance. We also show how Cook's life cycle approach (1995) lays out the creation and development of the cooperatives and provides a deeper understanding of the dynamics in GFM dairy cooperatives.

\section{Methodology}

\subsection{Data sources and analysis}

The five stages explained in Chapter 2 are taken into consideration in the following analysis based on a literature review, the analysis of secondary data and expert interviews. The secondary data was mainly gathered from three types of sources: firstly from the Brazilian Institute of Geography and Statistics (IBGE) which performed the agricultural census in 2006, secondly from dairy company reports. Finally it was also obtained from the dairy cooperatives' census performed by the "Organization of Brazilian Cooperatives", "Confederation of Dairy Brazilian Cooperatives", "Brazilian Agricultural Research Corporation Dairy" and "Center for Advanced Studies in Applied Economics - Esalq/ USP" in 2002 and reported on by Martins et al. in 2004. The agricultural census is conducted by the IBGE in 10-years cycles, the last two in the years 2006 and 2016. Since the data from the 2016 census is not available yet, data on the dairy sector from the 2006 census is used in this study in addition to data from dairy processors collected on a quarterly base by the same institute. IBGE's secondary data includes total milk production, productivity, number of farmers and processing companies, processing capacity and the geographic area of production and milk collection. The national census of dairy cooperatives completed in 2002 is the first, and up to now the only, national database registering the characteristics of the dairy cooperative system. Data from the follow - up census conducted in 2015 is still only available as a summary of selected parameters (Martins, Álvares, Barros, Nogueira Netto, \& Barroso, 2004; BRASIL, 2017). However, economic performance indicators on the company/cooperative - level are rarely available. A more detailed analysis based on such indicators, as recommended by Aramyan, Ondersteijn, van Kooten, and Lansink, (2006) including indicators of the four categories, "efficiency", "flexibility", "responsiveness" and "food quality", cannot be taken into account in this analysis. Additionally, little data has been found on previous and subsequent years. To close these gaps, 32 additional semi-structured interviews were conducted in 2015/16. These were with managers and directors of dairy cooperatives, with IOFs located in the GFM, also with directors of research and extension institutions, representatives from the Ministry of Agriculture, syndicates/unions and associations Table 2 represents an overview of the companies and organizations interviewed.

The questions varied according to the company/organization interviewed. We asked questions in various categories, which included government support (strategies for dealing with periods of crisis and/or declining government support; barriers to implementation of solutions), the evolution of the sector (difficulties in competing in the sector; expected solutions to sector problems; market trends and frauds) and information about a specific cooperative/IOF (volumes processed; management strategies; general problems faced to compete; competition against IOFs/cooperatives;) as relevant. The analysis of the interviews followed a systematic descriptive approach. The information and 


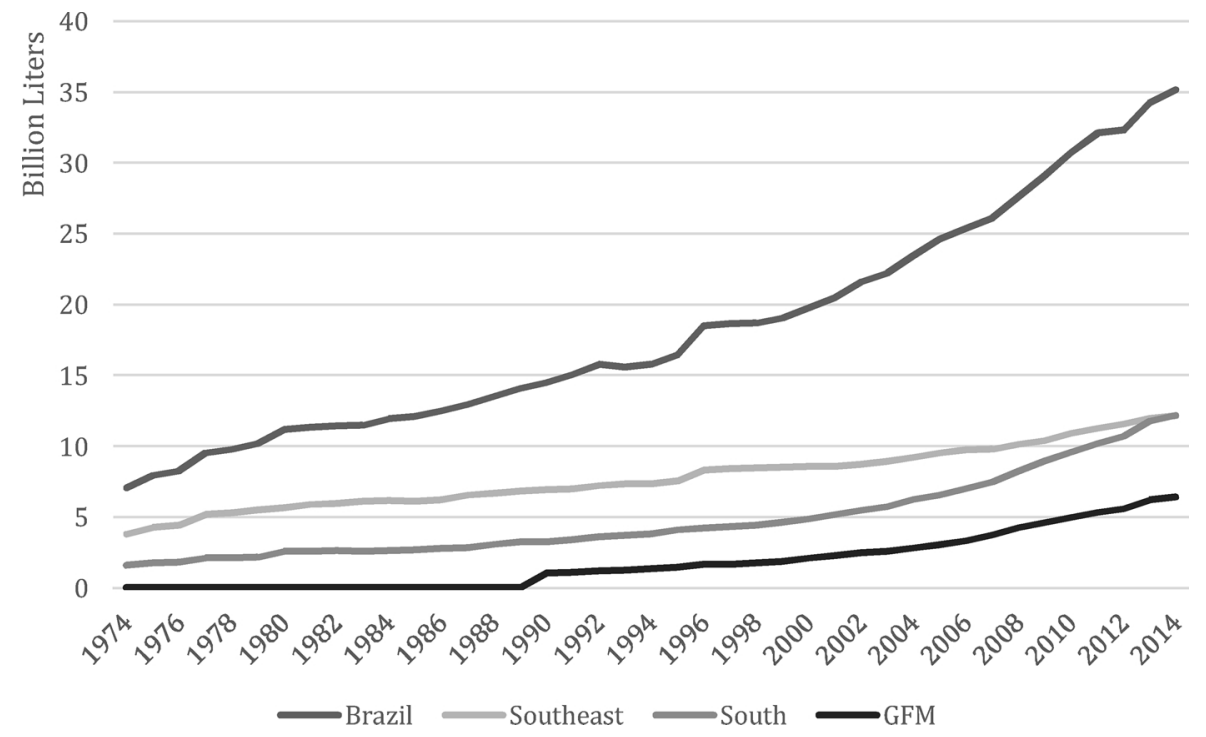

Fig. 2. Milk production (in billions of liters).

Source: Authors' elaboration based on data from IBGE (2014).

Table 2

Experts and institutes interviewed.

\begin{tabular}{|c|c|c|}
\hline Expert number & Institute/Company & $\operatorname{Size}^{\mathrm{a}}$ \\
\hline 01 & Cooperative & Large \\
\hline 02 & Cooperative & Small \\
\hline 03 & Cooperative & Large \\
\hline 04 & Cooperative & Large \\
\hline 05 & Cooperative & Large \\
\hline 06 & Cooperative & Medium \\
\hline 07 & Cooperative & Large \\
\hline 08 & Cooperative & Large \\
\hline 09 & IOF & Large \\
\hline 10 & IOF & Large \\
\hline 11 & IOF & Large \\
\hline 12 & IOF & Small \\
\hline 13 & IOF & Large \\
\hline 14 & IOF & Large \\
\hline 15 & IOF & Large \\
\hline 16 & Cooperatives Organization & \\
\hline 17 & Cooperatives Organization & \\
\hline 18 & Cooperatives Organization & \\
\hline 19 & Cooperatives Organization & \\
\hline 20 & Dairy Alliance & \\
\hline 21 & Dairy Alliance & \\
\hline 22 & Dairy industry union & \\
\hline 23 & Dairy industry union & \\
\hline 24 & Development Institute & \\
\hline 25 & Farmer & \\
\hline 26 & Farmer & \\
\hline 27 & Research and Extension Institute & \\
\hline 28 & Research and Extension Institute & \\
\hline 29 & State Agricultural Secretary & \\
\hline 30 & State Agricultural Secretary & \\
\hline 31 & State Dairy institute & \\
\hline 32 & Technical Assistance Institute & \\
\hline
\end{tabular}

a The different size categories are explained in Section 4.2.

data gathered is used below to enhance and complement information from the literature review and secondary data in order to provide details about the above mentioned five stages life cycle analysis. However, a structured content analysis, as proposed by Mayring (2014), could not be applied during our analysis due to the heterogeneity of experts and the corresponding variety of interview foci regarding time periods and content aspects.

\subsection{Description of the case "Brazilian dairy cooperative system"}

The information contained in this subsection was obtained from the two national censuses of dairy cooperatives. The first took place in 2002 and was compiled by Martins et al. (2004) and the second was in 2015 for which only a limited subset of data is as yet available in a summary (BRASIL, 2017). In 2002, central and singular ${ }^{3}$ cooperatives in Brazil were responsible for $40 \%$ (5.3 billion liters) of the total milk collected in whole Brazil, whilst $36 \%$ was collected in the country's southern region ${ }^{4}$. This amount had generated total revenue in the whole country of US\$ 1.82 billion in 2002 (RS\$ 4.91 billion in 2002 or RS\$ 0.93 per liter). Across Brazil 4.4\% was collected by 97 small scale cooperatives accounting for less than 19.5 thousand 1/day each. $11.8 \%$ was collected by 93 medium scale cooperatives accounting for 19.5 to 55.5 thousand 1/day and $83.8 \%$ by 98 large scale cooperatives accounting for more than 55.5 thousand 1/day (see Table 3). This distribution demonstrates the large variety of cooperatives with different scales of industrial processing, making it difficult to establish and promote brands as well as to compete in markets outside their region of origin. Their unit costs for milk collection, processing and commercialization also vary greatly due to differing economies of scale depending on company size (Becker, Parsons, Kolodinsky, \& Matiru, 2007; Belloin, 1988; Dalton, Criner, \& Halloran, 2002).

When looking closer at the major relational scheme of the cooperatives in the data from 2002, especially at the main role of singular cooperatives in collecting without processing, we observe that singular cooperatives collected $53.8 \%$ of the milk across the country, compared to only $44.6 \%$ in the South. In Brazil around $41 \%$ of the milk collected by the singular cooperatives was sold / transferred to central ones. Additional quantities are sold to, for example, IOFs. The share of milk resold unprocessed is much higher for smaller singular cooperatives than for the larger ones. Among singular cooperatives collecting less

\footnotetext{
${ }^{3}$ The major system in Brazil is the central-singular scheme. Singular cooperatives are members of a central cooperative, where the firsts collect the milk from farmers and deliver/sell most of their products to the second (or other IOFs depending on their exclusivity contract with the central cooperative), which are mainly responsible for processing and commercializing. This scheme contrasts to the centralized scheme where farmers deliver directly to the cooperative responsible for processing and commercialization reducing one transaction.

${ }^{4}$ The remaining shares were collected by the IOFs.
} 
Table 3

Characteristics of the dairy cooperatives.

Source: Martins et al. (2004).

\begin{tabular}{|c|c|c|c|c|c|}
\hline & Characteristics & $\begin{array}{l}\text { Small (less than 19.500 l/ } \\
\text { day) }\end{array}$ & $\begin{array}{l}\text { Medium (between } 19.500 \text { and } 55.5001 / \\
\text { day) }\end{array}$ & $\begin{array}{l}\text { Large (more than } 55.5001 / \\
\text { day) }\end{array}$ & Total \\
\hline \multirow[t]{5}{*}{ Brazil } & Quantity of cooperatives & $97(33,7 \%)$ & $93(32,2 \%)$ & $98(34 \%)$ & 288 \\
\hline & Milk collected in Million 1/day & $231(4,4 \%)$ & $620(11,8 \%)$ & $4.403(83,8 \%)$ & 5.254 \\
\hline & Members & $14.682(9,7 \%)$ & $34.374(22,8 \%)$ & $101.855(67,5 \%)$ & 150.912 \\
\hline & Average milk collected by each member in $1 /$ day & 43 & 49 & 118 & 95 \\
\hline & Milk industrialized & $17,7 \%$ & $26,0 \%$ & $49,4 \%$ & \\
\hline \multirow[t]{2}{*}{ South } & Members & $4.518(5,7 \%)$ & $13.748(17,2 \%)$ & $61.623(77,1 \%)$ & 79.891 \\
\hline & Milk collected in Million 1/day & $63,1(3,3 \%)$ & $170,1(8,9 \%)$ & $1679,8(89,9 \%)$ & 1.911 \\
\hline
\end{tabular}

than 19.5 thousand 1/day, $91 \%$ was sold/transferred to central cooperatives indicating their reduced capacity for marketing and commercialization. Cooperatives collecting more than 55.5 thousand 1/day transfer only $35 \%$ to central cooperatives, representing deeper participation in the market via commercialization.

The Brazilian raw-milk market in 2002 was largely controlled by cooperatives, given that there were no or only very few IOFs collecting milk and reselling it without processing. In this regard, $41 \%$ of the milk collected by the cooperative system is sold to other cooperatives or other companies, defining the scope of the raw-milk market in Brazil. From the total milk collected by the cooperatives only $44.2 \%$ is industrialized, thereof $49.4 \%$ by larger cooperatives. Cooperatives that industrialize less than $1 / 3$ of their milk earned a gross revenue of about US\$ 0.17 per liter while those industrializing more than $2 / 3$ of their supplies received about US\$ 0.34 per liter. Unfortunately processing costs are not available. They would otherwise allow for a better overview and comparison. Nevertheless, these numbers may represent higher revenue generated through value adding, allied with improved milk industrialization combined with better commercialization of processed products by larger cooperatives. It also highlights the importance of economies of scale in the dairy sector (Boysen \& Schröder, 2005; Mosheim \& Lovell, 2009).

The summary from the second national census of dairy cooperatives shows that the shares of total milk collected by Brazilian central and singular cooperatives have shifted in favor of the southern region (46.5\%) in relation to Brazil as a whole (35.5\%) despite an increase in total volumes (8.54 billion liters) (BRASIL, 2017). However, these procurement and capacity shifts were accompanied by very low capacity utilization rates in the cooperatives in 2015. Their installed processing capacity was reported as a total of 28 million liters/day with $47 \%$ idle capacity for whole Brazil. In the southern region the capacity represents 14.1 million liters/day with $41 \%$ of idle capacity. The total revenue of dairy cooperatives in Brazil is listed as around US\$ 2.3 billion (RS\$ 7.4 billion in 2015 or RS\$ 0.87 per liter), 38\% from UHT milk, $15 \%$ from powder-milk and $12 \%$ from pasteurized milk. Less value was added per liter of milk compared to 2002. Cheeses and dairy drinks account for less than $16 \%$ of the total revenue, evidence of a low share of value-added products in their product - portfolios (BRASIL, 2017).

The Brazilian dairy cooperative system accounted for 151 thousand members in 2002. Of those $9.7 \%$ belonged to cooperatives collecting less than 19.5 thousand $1 /$ day, $22.8 \%$ were associated to cooperatives collecting between 19.5 and 55.5 thousand $1 /$ day, while $67.5 \%$ were members of cooperatives collecting more than 55,5 thousand 1 /day. The average milk quantity collected per farmer was 431/day, 491/day and $1081 /$ day respectively. The average over the whole cooperative system was $951 /$ day, which is a very small number when compared to other countries like Argentina, Uruguay, Germany, USA and France (OECD, 2015). It also indicates the level of professionalization of farms and farmers, given that such a small production makes investment in hightech inputs unaffordable. This also leads to low adoption rates of new technologies due to limited capacity of investment. The southern region of Brazil concentrates more than half of the national cooperative members $(52.9 \%)$, but $78 \%$ of those are associated with cooperatives collecting more than 55.5 thousand 1/day. This picture highlights the importance of the cooperative system in the dairy sector for the country and especially for the southern region.

Producers delivering less than 1001/day represent $60.5 \%$ of all cooperative members in the country (but only $16.9 \%$ of the milk produced). 16.8\% deliver between 100 and $200 \mathrm{l}$ /day (representing 14.5\% of the milk), $10.9 \%$ deliver $200-5001$ /day (representing $18.7 \%$ of the milk) and only 5\% deliver 500-1000 l/day (representing $13.4 \%$ of the milk). More than $1000 \mathrm{l}$ /day were delivered by $6.8 \%$ of the farms but they account for $36.5 \%$ of the total milk produced. These percentages show the typical characteristics of small farms in the Brazilian dairy sector and represent the cooperatives' social role as sole operators in the sector collecting the milk of those farmers even when long distances make it unprofitable.

\section{Results: the life cycle of GFM's cooperatives}

Dairy production in southern Brazil emerged with European colonization in the $19^{\text {th }}$ century. This cultural aspect played a major role for the development of the dairy sector since the immigrants preferred to produce their own fresh milk rather than consume powder milk from the large dairy industries already existing in the southeast of Brazil (Minas Gerais and Sao Paulo). This production was initially organized as vacarias ${ }^{5}$ around a huge number of small cities spread throughout the territory and became a distinctive characteristic of southern Brazil. This greatly influenced the regional character of the dairy industry with its purpose of supplying the growing local market. The growth of urban areas in the first half of the $20^{\text {th }}$ century and developments in milkprocessing techniques allowed the displacement of milk production zones. Consequently, after the $1910 \mathrm{~s}$, IOFs as well as singular dairy cooperatives were formed in these emerging milk zones in southern Brazil (de Souza, 2014). However, in the GFM, a traditional rural area, the focus remained on other products, such as cereals, pork, and poultry, which were also organized in cooperatives; these businesses remained more important and developed at that time. Dairy production did not play an important economic role until the $1960 \mathrm{~s}$ even though it was always present among small family farms, which may be viewed as the incipiency of dairy cooperatives in the GFM (Escher, 2011b). The five stages of their life cycles, which partially overlap on a historical timeline (due to the entire sector consisting of numerous cooperatives with different timings as the unit of analysis) are described in detail below.

\subsection{First stage: economic justification}

Dairy production in southern Brazil has always been linked to land

\footnotetext{
${ }^{5}$ The vacarias were establishments (farms) specialized in production, purchase and sales of milk, located around the villages. They were the first commercial form of milk supply to urban centers in Brazil.
} 
dynamics and arose in the GFM as an alternative source of income adopted by small farmers who were excluded from other sectors. To better understand those dynamics, we developed a timeline of expansion of the dairy production that started in NW-RS and moved northward to W-SC and then SW-PR (see map in Fig. 1).

In the NW-RS region during the $1940 \mathrm{~s}$ and $1950 \mathrm{~s}$, wheat and soya beans were the main crops and economic priorities for farmers. Infrastructure development in transport intensified the production of these products and changed farmers' focus towards export orientation. These changes demanded increases in scale and, thus, a concentration on large farms and an exclusion of many small farms, which then had to find alternatives for their milk production. These excluded farmers started to form cooperatives and to reorganize the GFM dairy supply chain structure based on their experiences in the grain sector. They formed dairy cooperatives to supply inputs at affordable prices, provided services lacking at the time (such as credit and technical assistance) and countervail the market power of buyers or facilitate access to urban markets. In other words, these singular local cooperatives were formed for defensive purposes as they attempted to protect margins and wealth at the farm level (Magalhães, 2007).

The government made an important contribution to the development of the cooperatives at that time by implementing a plan of modernization and industrialization of agriculture throughout the country. The promotion of cooperatives was the main instrument deployed by the government to achieve its goals. Government institutions were established to support dairy farmers' cooperation and subsidized loans were offered to dairy cooperatives. In this top-down plan, cooperatives became highly dependent on state programs and national policies (Medeiros \& Padilha, 2015). In consequence, a significant number of small singular dairy cooperatives were founded in the NW-RS region of the GFM. Additionally and promoted by farmers, cooperatives specializing in other agricultural products adapted their plants or even converted completely to dairy in order to collect milk from small farms and increase their incomes. A similar dynamic happened a few years later in the W-SC and SW-PR regions among farmers excluded from pork and poultry sectors (institutional historic it's possible to find the foundation dates).

\subsection{Second stage: organizational design}

From the mid- $1960 \mathrm{~s}$ to the late $1980 \mathrm{~s}$, the development of dairy cooperatives was significantly affected by interference from the federal government, which monitored and controlled cooperative arrangements through direct intervention and by regulating the dairy market. In $1971^{6}$, Law 5764 was enacted, which established the institutional framework that still regulates the Brazilian cooperative system today. This law defined the legal status of cooperatives, rules for their formation and function, their representation system and support agencies.

Quality and sanitary standards for milk and dairy products were introduced in the mid-1960s. The Federal Inspection System (SIF) stamp, a sanitary surveillance compliance stamp, became mandatory in 1976. Compliance with the sanitary requirements in order to acquire this stamp was too expensive for many cooperatives, especially small ones. Consequently, “...this system promoted the foundation of large central cooperatives..." (Expert 18) and "...at the same time it forced many small dairies to exit the market" (Expert 17). These facts are also similarly expressed by Expert 23.

Additionally, from 1945 to 1991 , the government set guaranteed minimum prices for milk producers and maximum consumer prices for

\footnotetext{
${ }^{6}$ The Brazilian government first recognized and allowed the organization of agricultural cooperatives in 1903; however, rules concerning the organizational characteristics of cooperatives were established in 1932 with the Rochdale principles of cooperation.

${ }^{7}$ The authors translated the sentences under quotations from the interviews.
}

liquid milk (Carvalho, 2008) as well as commercialization and processing margins. Furthermore, milk producers and dairy cooperatives received large volumes of subsidized short and long-term loans from federal rural credit systems (Chaddad \& Jank, 2006).

\subsection{Third stage: growth and consequences}

During the $1970 \mathrm{~s}$, the Brazilian Government introduced measures to foster the adoption of new processing technologies and the professionalization of cooperatives. Thus, in the late 1970s, central cooperatives were formed to reorganize the singular cooperatives, increase their bargaining power and add value to the raw milk produced by small farms in rural areas in order to compete with IOFs in the large urban centers. However, these central cooperatives remained dependent on government programs supporting them with subsidized loans and fixed prices (Chaddad \& Jank, 2006).

In 1976, farmers pressured the Rio Grande do Sul Federation of Wheat and Soybean (FECOTRIGO) to create the central Cooperativa Central Gaúcha de Leite (CCGL) in the NW-RS region (Carvalho, 2012) (see Fig. 3 for timeline details). In 1970, the Companhia Riograndense de Laticínios e Correlatos (CORLAC) was founded in Rio Grande do Sul. Extremely important to small farmers, CORLAC was owned by the state and counted on 6,000 farmers and 22 processing plants. Two decades later, in 1993, it was transformed into the central cooperative COORLAC (Souza \& Waquil, 2008).

Many families that could not remain in the NW-RS region migrated to W-SC or to SW-PR, where pork and poultry production was growing and consolidated as farmers' main economic activities during the $1960 \mathrm{~s}$ and $1970 \mathrm{~s}$. However, from the early $1980 \mathrm{~s}$ the rapid growth of these industries led to the formal integration, exclusion and concentration of family pork and poultry producers who could not afford the high investments required. As a consequence, more than 52,000 farms were excluded from pork activities (Ferrari et al., 2005). These farms then also entered dairy production and a second generation of singular cooperatives was founded. The central cooperative AURORA ${ }^{8}$, a large marketing cooperative of the meat industry in W-SC, adapted to collecting milk from these singular cooperatives. The Cooperativa Central Catarinense de Laticínios (CCCL) also experienced rapid growth based on the littoral of Santa Catarina, where dairy production was concentrated at that time. A little later it expanded its coverage area to WSC by acquiring a processing plant in 1991 and consolidated as the main dairy industry in Santa Catarina (de Souza, 2009).

In SW-PR the Cooperativa Central Agropecuária Sudoeste Ltda. (SUDCOOP), established in 1977 for processing pork, began processing milk in the early $1980 \mathrm{~s}$ after acquiring three dairy processing plants in the region (Escher, 2011a) and commercialized through its brand Frimesa. Just after that, it transferred its company headquarters to the West of PR, where its activities were concentrated. The Cooperativa Agropecuaria Guarany Ltda. (CAPEG) was the second dairy cooperative created in the SW-PR region. The central AURORA also collected milk from singular cooperatives present in this area (Escher, 2011b). Both SUDCOOP and AURORA had their main businesses in the pork and poultry sectors. They invested in the dairy sector after pressure generated by the concentration of poultry and pork activities.

Between the late $1970 \mathrm{~s}$ and the early $1980 \mathrm{~s}$, the entire dairy industry experienced a boom in the GFM. The conversion of farms to dairy production, a positive institutional environment for cooperatives, growth in the number of consumers in urban centers, the creation of cooling stations to collect the milk and improvements in road infrastructure boosted the sector in this region. Leading companies invested in the expansion of the collection network and the construction of cooling stations, going beyond the industry's initial area of operation

\footnotetext{
${ }^{8}$ AURORA is a large marketing cooperative in the meat industry, with strong brands, lengthy experience in the market, and large distribution channels.
} 


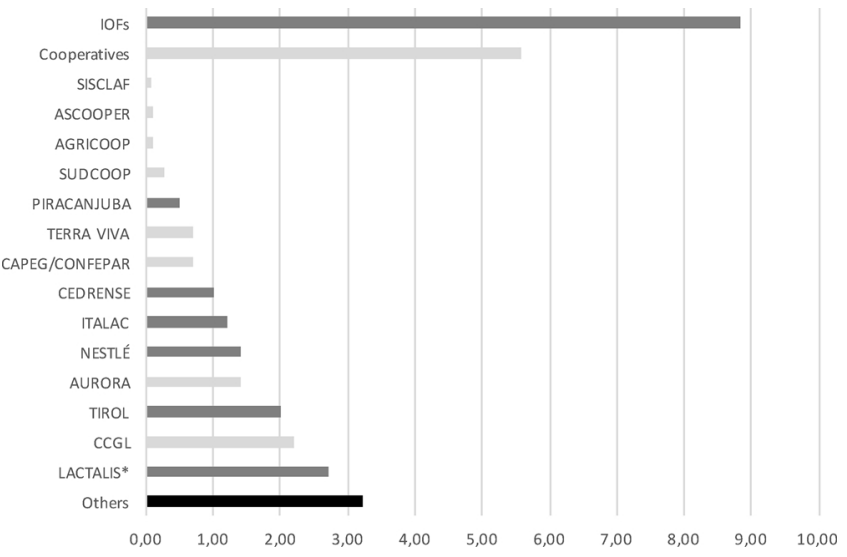

Fig. 3. Major players in the GFM dairy industry (capacity of collection in million liters/day).

and, in several cases, beyond state borders. Many small cooperatives were formed or adapted to collecting milk in the most remote areas, creating a large collection and distribution network. They benefited from output growth due to their proximity to members and the capillarity of their milk collection systems (Jank et al., 1999) and had an important role in ensuring market access for farm production. Central cooperatives were also successful. At that time, CCGL with its brand $E L E G \hat{E}$, formed by 35 singular cooperatives was responsible for $60 \%$ of milk procurement in Rio Grande do Sul. Over the same period, CCCL procured about $50 \%$ of the milk in Santa Catarina under the brand $D O$ VALE. In the SW-PR region, SUDCOOP and CAPEG were also responsible for the majority of milk procurement.

Since that time, dairy production has become the main economic activity sustaining local family farms in GFM, involving almost all the farms in the territory. The entire supply chain has been organized and sustained by cooperatives (Ferrari et al., 2005). This growth is also linked to crises in other sectors that excluded many farmers. As a result, the growth of the dairy sector as a whole and of the cooperatives in particular has been faced with increasing difficulties with regard to performance.

\subsection{Fourth stage: crisis and recognition of conflicts}

Despite their rapid growth during the $3^{\text {rd }}$ stage, GFM dairy cooperatives remained highly dependent on governmental paternalism. They were not exposed to market prices and competition, which undermined the natural development of their capacity and stimulus to compete. Additionally, “...huge unplanned investments were also made with subsidized loans creating idle capacities in cooperatives" (Expert 16). In the $1980 \mathrm{~s}$, after a national debt crisis and political change in Brazil, liberalization and market-oriented policies started being implemented. The Brazilian government reduced credit and subsidies for farmers and cooperatives until the dairy market was completely deregulated in 1991. The constitution of 1988 abolished the government's rights to interfere in cooperatives' arrangements. Thus, from late $1980 \mathrm{~s}$ and early $1990 \mathrm{~s}$, the politico-economic environment became more and more challenging for cooperatives (Chaddad \& Jank, 2006).

Furthermore, external economic influences at that time negatively affected all Brazilian industries. The petrol crisis forced the United States to change its monetary policy and increase interest rates. Countries dependent (in debt) on the U.S. dollar, such as Brazil, suffered from these new rates. Dairy cooperatives that traditionally acquired capital from external sources (loans) were badly affected, exposing their structural fragility as well as their lacking economies of scale and competitiveness (Escher, 2011b).

In addition to external pressure from the financial markets, there was also external pressure through competition from increasing imports of dairy products. This was a result of globalization but amplified in the early $1990 \mathrm{~s}$, when the Brazilian government reduced trade barriers. Urbanization and income increases among the Brazilian population made the country's dairy market more and more attractive for multinational agrifood processors and retailers, which increased their investments. In 1995, Mercosur countries established a common tariff replacing import barriers. Uruguay and Argentina, with their solid and advanced dairy industry, dumped high quality and cheaper products in Brazil. Less efficient and less agile enterprises were rapidly excluded from the market. National competitors were not able to adapt to the new market conditions and were displaced due to the resulting industry concentration and elimination of many medium-sized and small companies, especially cooperatives (Azevedo, Chaddad, \& Farina, 2004). This trend has been further reinforced by new technological advances such as UHT (ultra-high temperature) and air-tight carton packaging. This technological progress allows milk to be conserved for longer periods and its transport over greater distances. Milk became a commodity and the sector grew even more concentrated in industrial zones, undermining the main advantage of cooperatives-the local character of their collection and distribution networks, where especially in the dairy sector transport costs are high (Frenken, 2014).

A third kind of pressure on GFM dairy cooperatives appeared due to changes in the organizational structure of the Brazilian dairy supply chain, in particular an increase in the concentration of companies downstream. In this regard, the emergence of supermarkets led to increasing competition on national dairy markets and an attendant decrease in prices. UHT milk in particular, an important staple food, was used by supermarkets to attract consumers; they offered it at very low prices as part of their competitive strategy, which in some cases even led to negative margins - a typical example of a "lost leader" (Chaddad, 2007b).

IOFs and cooperatives represent the main point of competition in the procurement of milk. In order to deal with such issues ".... contract system was established between collectors and processors in order to ensure quantity and quality in supply" (Expert 09). However "...with such a degree of competition, leading companies failed to set standards of price and quality..." (Expert 14), enabling new agents to be created and to expand their market positions. This feature created a power struggle in the chain among retailers, the processing industry and the cooperatives' collection system (Experts 04, 08, 09, 14).

The sector was growing fast but the frequency of transactions in this sector is high and uncertainty of supply in the spot market is also high (Experts 01, 03, 04, 07, 08, 09, 11, 14, 15). Investments to increase production were necessary, consequently increasing the specificity of assets. The traditional cooperative ownership structure made it difficult for cooperatives to raise the necessary capital to invest. The absence of managerial skills and difficulties in raising equity capital from members generated important managerial and financial constraints for the cooperatives. Consequently, changes were necessary and the cooperatives had to restructure (Experts 01, 02, 04, 07) as described below.

\subsection{Fifth stage: restructuring}

As a consequence of these crisis and conflicts, after the mid-1990 s cooperatives and IOFs with low or no power of investment ended up being acquired by large IOF groups with national or international capital. Many supply/input (and/or cooperatives that only collected milk), especially singular cooperatives but also some central cooperatives left the market. Only "...those with better elaborated marketing strategies were able to persist even though facing financial constraints" (Expert 32). This development is also confirmed through similar statements by Experts 17 and 19.

The industrial concentration process that started in the $1990 \mathrm{~s}$ in the GFM dairy sector had distinct moments. As a result, during the first phase in the early $1990 \mathrm{~s}$, large foreign capital agribusiness groups entered the sector, attracted by market liberalization and tax incentives 
in Brazil. "...The strong competition generated by these companies characterized this period" (expert 20).

For instance, the IOF Parmalat ${ }^{9}$ (Table 4), pursuing an aggressive growth strategy and global corporate marketing policies, entered the GFM in 1993 (Carvalho, 2008). A significant consequence of its entry was the displacement of the main dairy region from the eastern-center to the NW-RS, competing directly with the central cooperative CCGL in sales and in milk procurement.

After the deregulation of the dairy sector, Parmalat introduced the first movement of professionalization and strong competition in the dairy industry in GFM. The company forced farmers, cooperatives and IOFs to become more efficient, change their strategies and organizational structures, or exit. Singular cooperatives either exited or invested in equipment for bottling UHT milk, which was generally financed by Parmalat. This process created an industry with little bargaining power from the production side and tightly dependent on large processing companies (Experts 24 and 28).

The central cooperative CCGL could not resist the strong competition from Parmalat and exited in 1996. By this time Parmalat and AVIPAL, who had bought CCGL, controlled $70 \%$ of the market in RS, characterizing an oligopsony. The greater concentration in the processing stage of the supply chain, referring to Expert 23 "...directly affected the prices paid to singular cooperatives and producers", a priceeffect that is also described by Expert 16.

Also in 1996, the central CCCL lost its main singular supplier cooperatives in western SC. These cooperatives formed the Cooperativa Central Agromilk, a society made up of 11 singular dairy cooperatives headquartered in W-SC. Agromilk delivered its milk to another central cooperative acquired by Parmalat two years later.

The second period of industrial concentration in the mid-2000 s was characterized not only by the entry into the sector of large national IOF agribusiness conglomerates but also the restructuring and new growth of singular and central cooperatives (explained in the subsection "New Life Cycle" below) “...supported by government incentives and increased credit access" (Expert 16). Different reasons were fundamental for the expansion of national companies (IOFs and cooperatives).

First, in the late $1990 \mathrm{~s}$, Parmalat was involved in a fatal corruption scandal and consequently a major crisis. "The closure of the company's activities offered a huge opportunity for national companies to enter the dairy sector..." (Expert 2). Second, in the early 2000 s, large pork and poultry industries reduced their activities in the GFM. They moved from the GFM to the center-west of the country, attracted by tax incentives and the proximity of the corn and soya bean production zones. These companies reduced procurement contracts and excluded less efficient farms from the pork and poultry sector once again. Third, the Brazilian government gave national IOFs and cooperatives increased access to credit. However, cooperatives needed a longer time to recover from the $1990 \mathrm{~s}$ crisis in comparison to IOFs, which already had access to the financial market and other sources of capital in addition to having more qualified managers (Experts 01, 02, 03, 06, 18, 19, 22, 29, 30).

At this time, the quality and sanitary requirements became more restrictive with the "Normative Instruction 51" (IN-51) in 2002. New technical standards required farmers to invest in refrigerated tanks. It also became mandatory for dairy processors to collect milk from producers in refrigerated trucks. These developments induced scale effects and led to the closure of cooling stations due to the tankers' ability to collect milk over longer distances, which again undermined singular local cooperatives' competitive advantage and their traditional procurement systems (Chaddad, 2007b).

Enterprises with capital to invest used the opportunity to expand their activities into the dairy sector. The most important example is the

\footnotetext{
${ }^{9}$ Parmalat is an Italian food product company founded in 1961 in Parma. The company arrived in Brazil in 1974.
}

IOF BRF-Brazil Foods ${ }^{10}$ Group (Table 4), which started operating in the dairy segment in 2000. In early 2008, it was the second largest dairy company in Brazil and the main competitor for cooperatives and other IOFs in the zone (de Souza, 2014). Fig. 3 shows the differences between cooperatives and IOFs according to their collection capacity. . A summary of the life cycle stages is described in Table 5 .

The increased industrial concentration generated by national capital groups in the $2000 \mathrm{~s}$ helped to improve national industry competitiveness in face of foreign companies in the sector, forming an oligopolistic structure. The procurement of raw milk is the main point of competition between companies, generating significant impacts on producers (Experts 02, 04, 05, 10, 12, 13, 16, 31). The dairy industry started to undergo a process of transition, with a view not only toward the regional market, as had been the case until the early $1990 \mathrm{~s}$ in Brazil, but also toward greater competitiveness in the international market. To survive, producers and the industry as a whole had to increase their scale as mentioned by Experts 21, 25, 26, 27 and 28.

\subsection{New life cycle (3rd stage)}

According to Cook (1995), after restructuring a new life cycle begins and that was the case for GFM dairy cooperatives. Restructuring trends increased in the mid-2000s: after the crisis in the early $1990 \mathrm{~s}$, cooperatives with huge debts and farmers pressured the government to create measures for mitigating their difficult situation. As a result, policies for restructuring and capitalizing agricultural cooperatives were created in 1998 but especially in 2003, which was characterized by the new political environment that developed when the Workers Party assumed leadership of the central government (Alves, 2003). Credit was released for investments in the modernization of plants and the professionalization of managers. Then a period of rapprochement between cooperatives and the government began. Farmers responded by creating new singular cooperatives, associations of cooperatives and central cooperatives for joint commercialization and processing in a strategy to add value to their production (Schubert \& Niederle, 2011).

As predicted in Cook's framework, a new life cycle had begun. With the $1^{\text {st }}$ and $2^{\text {nd }}$ stages already established in the first cycle, a second phase of growth (3rd stage - new cycle) took place. This growth occurred in parallel with the $5^{\text {th }}$ stage of the first cycle, when other cooperatives were restructuring.

At this time, dairy cooperatives developed following two different organizational models in the GFM: first a productionist model predicting the concentration and specialization of production and the high intake of external inputs with no space for many small producers.Second, a model favoring balanced production systems, diversification of production and sanitary hygienic standards appropriate to the reality of family production units-the cooperative networks (Ferrari et al., 2005).

The productionist model resulted from important investments by large central cooperatives in the dairy sector. Cooperatives from the poultry and pork sector but also traditional dairy cooperatives invested in processing plants and in marketing strategies.

Since the late $1980 \mathrm{~s}$ the central cooperative AURORA had only collected milk from their farmers through its singular cooperatives, processed the basic steps (homogenization and pasteurization) and sold it on the market. However, in 2004 AURORA decided to process the production of milk (products ready for consumption) only through the brand AUROLAT, adding more value to the 7,200 associated cooperative members' production. It began processing milk mostly after pressure from member associates. This diversification was also a result of farm diversification and the evolution of agricultural production dynamics in the GFM. SUDCOOP also collects $36 \%$ of its processed

\footnotetext{
${ }^{10}$ This company acted primarily in the poultry and pork sector, where its main business activities are focused. Its headquarters are in W-SC.
} 
Table 4

Chronology of the dairy companies evolution in the GFM.

Source: Authors' illustration based on companies' reports available online on companies' homepages and direct personal interviews; IOFs highlighted in dark grey and cooperatives in light grey.

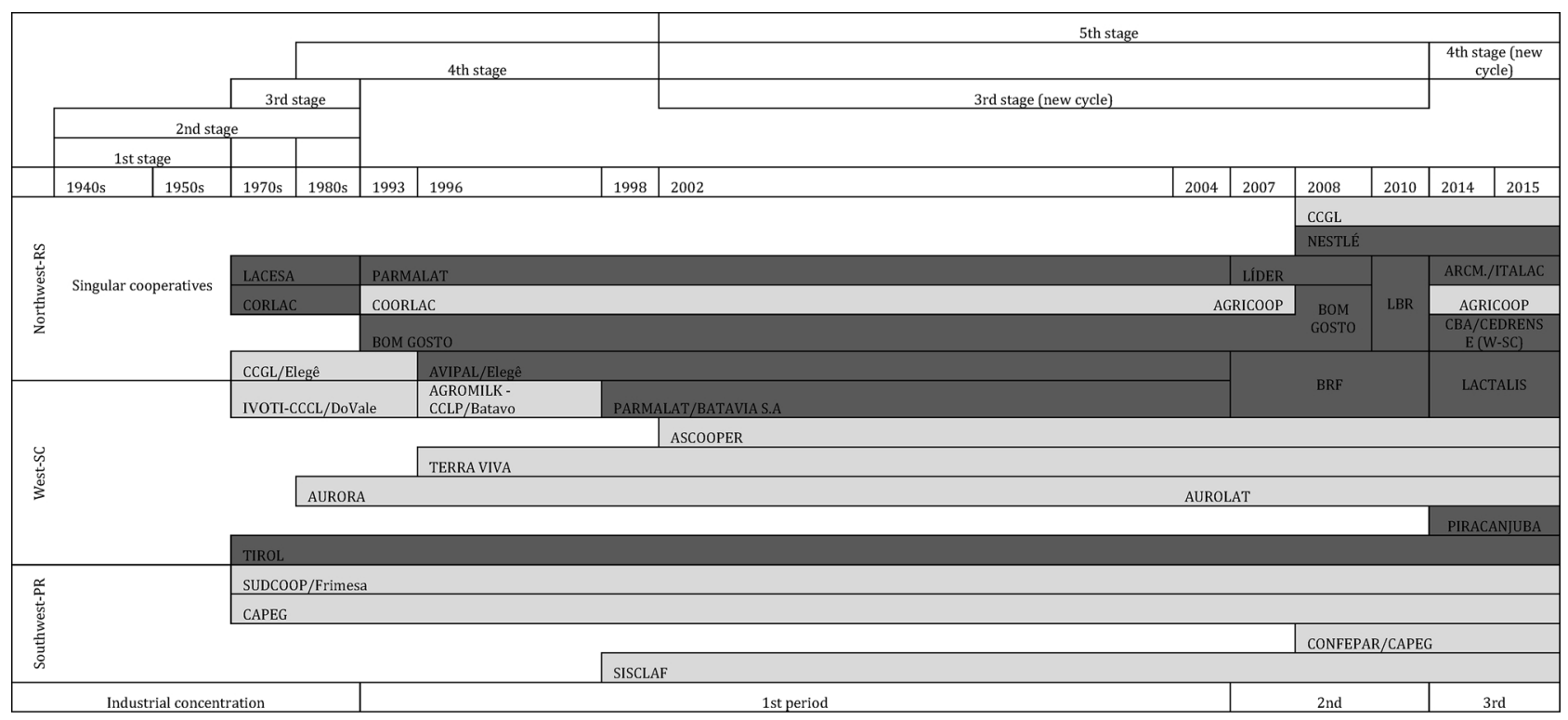

Table 5

Summary of life cycle stages.

\begin{tabular}{|c|c|}
\hline Stages & Main Findings \\
\hline 1 st - Economic justification (1940s - $50 \mathrm{~s}$ ) & $\begin{array}{l}\text { Exclusion of farmers from various sectors prompted the creation of singular cooperatives supported by government } \\
\text { incentives. }\end{array}$ \\
\hline 2nd - Organizational design (1960s - $80 \mathrm{~s})$ & $\begin{array}{l}\text { Establishment of the cooperatives law and quality and sanitary standards for dairy products. The government } \\
\text { intervened directly in market prices. }\end{array}$ \\
\hline 3rd - Growth and consequences (1970 s - early $90 \mathrm{~s}$ ) & $\begin{array}{l}\text { Implementation of government measures to foster technology adoption and professionalization. Creation of large } \\
\text { central cooperatives. Migration of farmers towards the North. Expansion of the dairy sector in GFM region. Formation } \\
\text { of a large connection and distribution network. }\end{array}$ \\
\hline 4th - Crisis and recognition of conflicts (1990 s) & $\begin{array}{l}\text { Liberalization and market-oriented policies implemented in the country. Reduction of government support and trade } \\
\text { barriers. Less efficient companies exit the market, especially cooperatives. }\end{array}$ \\
\hline 5th - Restructuring (mid $1990 \mathrm{~s}-\mathrm{mid} 2000 \mathrm{~s}$ ) & $\begin{array}{l}\text { Exiting cooperatives are acquired by large national and international IOFs. Industrial concentration and competition } \\
\text { increased. Large central cooperatives exit. There was an increase again in national companies after new government } \\
\text { supports. The national industry became more competitive, but cooperatives took longer to regrow. }\end{array}$ \\
\hline $\begin{array}{l}\text { 3rd New life cycle - Growth and consequences (mid } \\
2000 \mathrm{~s} \text { ) }\end{array}$ & $\begin{array}{l}\text { More supporting measures from the government. Cooperatives again grow, modernize and professionalize. } \\
\text { Development of the productionist model and the cooperative networks. }\end{array}$ \\
\hline $\begin{array}{l}\text { 4th New life cycle - Crisis and recognition of conflicts } \\
\text { (early } 2010 \mathrm{~s} \text { ) }\end{array}$ & $\begin{array}{l}\text { Cooperatives formed and expanded without taking into account long-term survival strategies. Crisis of } 2008 . \\
\text { Difficulties in developing marketing strategies to increase their market shares and market power in the face of large, } \\
\text { often global IOFs. Rise of political problems in the direction of cooperatives. Most cooperative networks decline. } \\
\text { Multinational IOFs install processing plants in the region. Large mergers and acquisitions. }\end{array}$ \\
\hline
\end{tabular}

volume in the SW-PR region. Market- and consumer-oriented cooperatives such as AURORA and SUDCOOP are competitive and successful.

Implementing another marketing strategy, after 12 years out of the market, the central cooperative CCGL restarted its activities in the GFM dairy sector in 2008 with new processing plants. Also in 2008, CONFEPAR, a cooperative from the north of PR, installed a processing plant in the SW-PR region.

Concentration and exclusion also led to the formation and organization of socio-economic actors into a new profile, called cooperative networks, the second organizational model of the cooperatives. For the purpose of analysis, these networks can be considered cooperative associations. These cooperative networks were founded by an initiative of social organizations to mitigate concentration and ensure market access for excluded farmers. The reorganization was a reaction to the policies adopted by large agribusiness firms in the region favoring large-scale production (Anschau, 2011).
The networks achieved a reasonable level of competitiveness with regard to access to raw milk, especially from a production perspective. Their main advantages were a widespread system of milk collection and their proximity to members in most remote regions, as confirmed through the interviews. Cooperatives and networks primarily supported farms in the organization of production, improvement of milk quality and working conditions, reduction of production costs, technological adaptation, the use of credit and joint commercialization of production (Escher, 2011a). These networks included COORLAC ${ }^{11}$ in NW-RS, ASCOOPER and TERRA VIVA in W-SC, and SISCLAF in SW-PR.

COORLAC (Cooperativa Riograndense de Laticínios e Correlatos) was formed in 1993, when the former CORLAC came under the

\footnotetext{
${ }^{11}$ COORLAC acquired cooperative status only in 1993. Before that, it was owned by the state and had different names, such as SABEL (1936), ELSA (1946), DEAL (1948), and CORLAC (1970).
} 
management of cooperatives (see $3^{\text {rd }}$ stage in the first cycle). COORLAC comprised a central cooperative, 4 regional centers, and 22 singular cooperatives. According to the 2002 Brazilian Association of Milk Producers, it occupied the seventeenth position in the national ranking of companies in volume production, with an average of 20 million liters per month and seventh place among producers with 6,000 members. The central cooperative commercialized through the brand CORLAC (de Souza, 2007).

Since 2001 in the W-SC region, this dynamic has led the formation of singular dairy cooperatives of family farming, with the support of family farming unions, associations of family farms, and institutes. From this first organization, seven cooperatives associated and created the ASCOOPER (Associação das Cooperativas Produtoras de Leite do Oeste Catarinense) in 2002. Some years later it grew to twenty singular cooperatives and brought together 43 municipalities covering 3,370 small farmers, who were undercapitalized and normally excluded from other production systems due to low production scales. In 2011, it produced a volume of 55 million liters of milk. It arose from the organizational needs of small local cooperatives that aggregate family milk producers in the municipalities of the W-SC region. Even today, ASCOOPER does not have processing plants or joint commercialization. It acts exclusively through the organization and representation of cooperatives. Thirty percent of its production is sold to other cooperatives, while $70 \%$ is sold to IOFs (Iliopoulos \& Cook, 2013).

Another important cooperative network in W-SC was the Rede Cooperativa Intermediária, which was coordinated by workers of the Landless Movement (MST). During the $1990 \mathrm{~s}$, the number of farmers who involved in dairy production increased. Simultaneously, during harvest seasons with surpluses, producers received only $30 \%$ of the market price for milk. In response, the MST felt the necessity to add value to the farmers' products as an alternative to a rural exodus, leading the MST leadership to process the milk (ready for consumption) produced in the settlements. Consequently, investments were made creating COOPEROESTE, which processed the milk through the brand TERRA VIVA. The first processing unit of milk and cheese was established in 1996. In 2015, it processed 700,000 liters per day from 6,000 families. Their processing operations are concentrated in one plant (Terra Viva, 2015). Today, COOPEROESTE is considered a successful, market-oriented network.

In the SW-PR region, SISCLAF (Sistema de Cooperativas de Leite da Agricultura Familiar com Interação Solidária) system had the same purpose as COOPEROESTE in the W-SC region. In 2015, it consisted of 16 singular cooperatives and one central cooperative. Its earliest singular cooperatives were formed in 1998, and the central cooperative in 2004. Singular cooperatives have municipal scope and serve to organize groups of producers. They are integrated in regional centers, negotiate with regional partners, coordinate technical assistance and control the collection and the quality of milk. The central cooperative's role is to establish strategies and projects for the whole network system, to represent it and to provide support services for other member cooperatives. The system had 5,000 associates, who produced on average about 6 million liters of milk per year in 2009 (Escher, 2011a). SISCLAF invested in small processing plants, created joint ventures with other cooperatives and bought services from other companies with idle industrial plants to process their products (David \& Garcia, 2009). This network also acquired a processing plant from one of its debtors. Additionally, SISCLAF frequently invests in marketing (Escher, 2011a).

\subsection{New life cycle (4th stage)}

This second phase of the "growth" stage in a second life cycle, during which cooperatives which were formed in the GFM, expanded without taking into account long-term survival strategies and so was again followed by crisis and recognition of conflicts $\left(4^{\text {th }}\right.$ stage new cycle). Thus, despite the rapprochement of GFM cooperatives with the Brazilian government in the mid-2000 s (through governmental support actions), cooperatives are again facing difficulties in developing marketing strategies to increase their market share and power in the face of large, often global IOFs. Since most cooperatives do not have the marketing know-how and industrialization structure to ensure the commercialization of products they tend to exit because they act exclusively to collect and negotiate the total volume of production. Cook (1995) argues that these cooperatives generally do not survive the second stage. Furthermore the social connotation of cooperatives mentioned in subchapter 4.2 implies additional high collection and transaction costs and consequentdegradation of the cooperatives' competitiveness (Rangasamy \& Dhaka, 2007). The whole process of strategic management, such as development and implementation of efficient collection processes and provision of technical assistance is therefore more complex for the cooperatives due to their spread and fragmented structure. This scenario can be made worse by the poor professional qualification of managers and directors in a large number of cooperatives (Ortmann \& King, 2007). Their initial advantage of scale economies has rapidly been offset by management and organizational issues plus decreasing profit margins. Allied to this deficiency, Expert 07 mentions that "...there is a dispute in the political field as well as in the direction of cooperatives". This statement is also confirmed by Experts 08, 16 and 17.

These aspects lead to problems in the allocation of formal control rights (Chaddad \& Iliopoulos, 2013). As a consequence, trust and cooperation ties, which supported those cooperatives and networks, have been damaged. Deng and Hendrikse (2014) argue that the social capital of cooperatives decreases over their life cycle and cooperatives' comparative advantages may disappear. Ben-Ner (1988) made a similar statement concluding that growth encourages members to pursue higher personal incomes. In order to avoid this problem, the income rights structure must change appropriately and leaders should maintain and develop social capital over time.

After the crisis of 2008, the central cooperative COORLAC dropped out of the Brazilian dairy sector and sold the brand CORLAC and its industrial operations. It was renamed AGRICOOP (Central Cooperative Agrofamiliar) and in 2015 only 10 singular cooperatives were part of its system. Its main function was the organization of producers and the collection of milk. In 2014, AGRICOOP acquired a processing plant and began developing new business models (Agricoop, 2015).

ASCOOPER lost famers and cooperatives to other companies. Today, this network includes only 14 cooperatives, totaling 2,572 associated farmers and a milk production of 38 million liters/year.

Recently the Ministry of Agriculture, Livestock, and Supply (MAPA) decided to unify the national sanitary inspection systems. They are currently separated into federal (SIF), state (SIE), and municipal (SIM) bodies and only allow commercialization within their individual territories. SIF has more restrictions and also allows export. Additionally, the ministry intends to create the Brazilian System of Animal Products Inspection (SISBI-POA) (MAPA, 2016). As in 1976, when SIF became mandatory, this initiative might increase export opportunities for all companies and, at the same time, exclude those who are unable to afford the necessary improvements.

A third period of industrial concentration started in 2013/2014. New multinational IOFs specialized in dairy processing settled in GFM, having been attracted there by promising market opportunities in this region and its solid dairy supply chain. Large mergers and acquisitions characterize this most recent period (Schubert \& Niederle, 2011). Internally, the financial crisis of 2008 depreciated the Brazilian currency (Reais R\$) so multinationals invested in Brazil in order to produce with lower costs. Externally, the EU extended its policy of outsourcing production of low-value-added products, this measure affected the dairy sector in 2015. Anticipating the fall of the dairy quota system in the EU, some companies invested in emerging countries and GFM was considered an attractive zone for those multinationals.

The French group LACTALIS, owner of Parmalat International, acquired all the dairy activities in the group BRF-Brazil Foods. That 
started a strong movement of international expansion. In 2015, it became the largest group in the dairy sector in GFM (Fig. 3) and the second largest in all of Brazil. Expert 29 states that "the arrival of the group LACTALIS in the GFM in 2014 supported the process of professionalization in the dairy supply chain and pushed cooperatives and IOFs to increase efficiency or exit the market". This development is also described by the Experts 16, 20, 21, 23 and 30.

This new industry structure resulted in a spatial reorganization of the sector. The structural pattern of production units changed from small factories and dairy plants to production concentrated in industrial plants with higher production capacities. These new structures benefit from economies of scale and break with the former regional character of the industries located in southern Brazil. These changes have increased competitive pressure in the dairy sector, which forces all companies, IOFs and cooperatives who intend to remain active, to search constantly for innovation along the entire supply chain (de Souza, 2014).

\section{Discussion and conclusions}

By analyzing the overall evolution of cooperatives in the GFM region in southern Brazil historically combined with the role of institutional, political and economic environment in their competitiveness, it becomes evident that close links exist between the failure of cooperatives and government interventions. This became evident through the application of the life cycle of cooperatives approach developed by Cook (1995), a valuable tool for analyzing the entire process-from creation to exit-of cooperatives in the dairy sector of southern Brazil. Using the region as a unit of analysis is also appropriate for understanding these dynamics at a regional level, which confirms and extends the earlier study by Chaddad (2007b). When doing so, it becomes obvious that the fundamental assumption in strategic management literature that firms' strategies reflect external conditions as well as internal resources and capabilities (e.g., Johnson, Whittington, Angwin, Regner, \& Scholes, 2014), is also true for the cooperative sector. Furthermore, the findings support the contingency theory view that external contingencies have a strong influence on firm performance (Donaldson, 2001). Our findings are also in line with Francesconi and Ruben (2008), who argued that agri-cooperative business in developing countries is likely to be less adaptive and may face limited sustainability for external reasons (missing markets and invasive governance) as well as managerial procrastination. In this study, the authors showed that public intervention to promote the formation of rural cooperatives is often too invasive (as has been the case in Ethiopia), triggering collective dependency rather than entrepreneurship.

Our analysis identified three relevant phases: an initial period of growth and expansion in the $1960 \mathrm{~s}$ and $1970 \mathrm{~s}$, followed by huge crises in the $1980 \mathrm{~s}$ and $1990 \mathrm{~s}$ and then a period of recovery and growth beginning in $2000 \mathrm{~s}$. These phases are linked to differing public policies, especially with regard to credit access, the internal and external economic environment and the foundation of new institutions. Our findings run counter to those of Ben-Ner (1988) and Pérotin (2006), who concluded that cooperatives grow counter-cyclically, that is, they are born during crisis. However, in a developing country as per our study, this premise does not apply. During a crisis, the government tends to abandon incentive programs for cooperatives, leading them to fail. The political environment has more influence than the economic one. Cooperatives that are formed as a result of political incentives are therefore more likely to fail when those incentives no longer exist. It is important to emphasize that the Brazilian economy grew faster and unemployment declined quicker when not only cooperatives but also medium and small IOFs were supported. The main problem is that there were no concurrent measures to make them independent of government support so they could survive alone when the government removed the incentives. Apart from the observation on non-counter-cyclicality, the results of this study clearly show that after the first completed life cycle, there is neither a continuing phase of sector stabilization nor a restart from new as conceptualized by Cook (1995). Instead, concurrent with the $5^{\text {th }}$ stage of the first life cycle, a number of cooperatives in Brazil entered the $3^{\text {rd }}$ stage of a second life cycle much earlier than others. These findings on the one hand provide proof of overlapping life cycles and on the other hand the restart of further life cycles at more advanced stages, depending on the external contingencies and internal characteristics of companies in any given sector and country. Since such developments have never been conceptualized and observed before, this study adds further theoretical advances to the existing academic literature on Cookös (1995) life cycle approach.

Currently, dairy cooperatives in GFM are again under huge economic pressure due to a spatial reorganization of dairy production and changes in the structural pattern of production units. New business models and strategies aimed at disconnecting them from government aid plus new approaches to market competition are necessary to promote competitiveness in this growing sector and maintain the viability of family farms. Hoff and Stiglitz (1990) suggested that cooperatives in developing countries formed from external capital (government or aid projects) are generally passive. Similarly, Wouterse and Francesconi (2016) found that cooperatives are healthier if they do not receive external support for their establishment, most likely because this reduces the need to provide an economic justification for that establishment.

According to our results, historical dynamics in the GFM dairy sector show that supply and/or input cooperatives tend to leave the market, whereas marketing cooperatives remain. Directors of cooperatives are aware that cooperatives and associations that continue only collecting and selling milk will disappear. They understand the weakness of this role (David \& Garcia, 2009). This finding parallels earlier research on strategic management in cooperatives, which revealed that strategic positioning is a decisive determinant for a cooperative's success (Theuvsen \& Franz, 2007).

Our findings have manifold managerial implications. First, economies of scale, optimization of organizational and governance structures, increase of capital, correct and efficient investments in marketing and commercialization are potential solutions for cooperatives seeking to avoid market exit. Managers should therefore have a plan of action geared towards merging small cooperatives in order to achieve gains in scale and a market/consumer-oriented focus. The creation of centralized structures instead of a singular-central system is one possible solution that should be analyzed in greater detail.

Furthermore, improvement of milk quality through enhanced quality controls in rural areas and productivity through industrialization of production are considered of special importance. In this regard, a higher degree of professionalization within boards of directors among GFM cooperatives and farms is needed to introduce these changes, which in turn are necessary for survival in this fast changing environment. This professionalization could be achieved by the following 5 recommendations drawn on Chaddad (2007b), 2007a) and Cook's and Iliopoulos' (2016) suggestions and adapted to our case:

1 Focus on a single economic activity or create independent business units to provide services to specific groups of producers. In this regard, the central cooperatives must separate the dairy business in order to establish an independent administration and improve and professionalize the management of the dairy production process. A second option would be to create separate capital and service pools (Iliopoulos \& Cook, 2013).

2 Control the quantity and quality of supply through defined member frameworks and marketing contracts. This could be a challenge since many farms are very small and have low technology adoption. The establishment of contracts without any support could exclude many such families from the sector. To overcome this problem and implement such contracts, cooperatives must invest in programs of extension and quality training for farmers as well as investment 
capital financing. Farmers who want to deliver to the cooperatives should be required to participate in specific training to professionalize their activity. Cooperative networks should adopt the same mechanisms. Communication with members must also be further developed together with contracts.

3 Redefine contractual relationships with members to offer them incentives to invest risk capital, or seek new sources of capital in the market. Here, the cooperatives law has to be revisited. The Brazilian cooperatives law (Law No 5.764, 16/12/1971) does not allow the formation of New Generation Cooperatives (NGC) to overcome the five problems of vaguely defined property rights (VDPR) (Cook \& Iliopoulos, 1998). Therefore, as yet, none of the dairy cooperatives have shifted to NGCs in the Brazilian dairy sector. Updates to this old law of cooperatives are needed to provide some flexibility and allow the creation of mechanisms to avoid VDPR issues (Cook, 1995) by such means as developing asset appreciation mechanisms and equity capital plans, increasing share liquidity by creating delivery rights and introducing new membership policies. A variety of different governance structures with different allocations of decision and residual rights are required in order to overcome the aforementioned problems (Chaddad \& Cook, 2004). To allow for those structures, cooperatives must adjust and remake their bylaws (Hendrikse \& Feng, 2013). This conclusion is also valid for other cases and (developed) countries: Rebelo and Caldas (2015) derived the same conclusions in their analysis of the role of agricultural cooperatives in Portugal, showing the need for cooperatives to be more flexible in their organizational structure to solve a wide range of their current problems.

4 Proportional investment capital, division of profits and voting rights in accordance with the cooperative use (milk production) in order to control the opportunism of "free riders". The actual law does permit proportionality according to use. However political issues, especially the abuse of power (control and influence-cost problems) in the administration of cooperatives results in very few co-ops adopting proportionality systems. Such a system must be extensively adapted with specific rules for avoiding power abuses in order to pursue an optimal allocation of ownership.

5 Market orientation. Focus on customer satisfaction. Here the main challenges are the size of cooperatives and level of management skills. We recommend the fusion of cooperatives to increase size and bargaining power so creating a competitive yardstick. The marketing cooperatives (CCGL, Aurora and Sudcoop) should lead this strategy. The first movement would be to separate their dairy activity into an independent structure. The next would be to merge with other cooperatives: Capeg/Confepar, Terra Viva, etc. This process will lead to a transformation from the central/singular scheme into a centralized structure with many organizational advantages, beginning with processing in the high-value-added food industry. Our recommendation for the cooperative networks is similar. It is necessary to make investments in processing plants and marketing actions and to merge with other marketing cooperatives or create strategic alliances or joint ventures with them.

We also strongly recommend collecting additional information through new censuses of dairy cooperatives and combine them in a database whereby experts could perform a more detailed follow-up. Furthermore, our findings have a variety of implications for political decision-makers, for example with regard to how politics addresses the competitiveness of cooperatives in the GFM dairy sector.

The same industry that produces an income of about US $\$ 25$ billion annually expels, on average, one producer every $11 \mathrm{~min}$. The general head of EMBRAPA Dairy argues that cooperatives are the best way to deal with such problems since they work on reducing social problems caused by economic conditions. Thus, today's cooperatives still very much reflect the mission that once inspired the rise of the cooperative movement (Grosskopf, Münkner, \& Ringle, 2010).
This study is limited by its qualitative descriptive nature. Further quantitative analyses are needed in order to confirm its results. In this regard, a spatial analysis of performance in the Brazilian dairy sector is being developed in order to identify spatial influences on the efficiency and productivity of the various production zones in Brazil. Furthermore, the determinants of the performance of dairy cooperatives in the state of Paraná, in the southern region of the country, are also being quantified.

\section{Funding}

This work was supported by the Coordenação de Aperfeiçoamento de Pessoal de Nível Superior (CAPES).

\section{Acknowledgment}

We would like to thank Professor Fábio Ribas Chaddad for his advice on this work. Thank you very much and rest in peace dear Professor.

\section{References}

Agricoop, 2016. Accessed through http://www.agricoop.com.br/ in 16.06.2015

Alves, A. G. M. P. (2003). As Cooperativas Agropecuárias e o BRDE - Histórico, Situação Atual e Perspectivas. Diretoria de Planejamento. BRDE November.

Anschau, C. T. (2011). Redes Cooperativas Da Bovinocultura de Leite e o Desenvolvimento Do Oeste Catarinense. https://www.unochapeco.edu.br/static/data/portal/downloads/ 926.pdf.

Aramyan, L., Ondersteijn, C., van Kooten, O., \& Lansink, A. O. (2006). Performance indicators in agri-food production chains. Quantifying the agri-food supply chain. Netherlands: Springer49-66.

Azevedo, P. F., Chaddad, F. R., \& Farina, E. M. M. Q. (2004). The free trade area of the Americas and the food industry in Brazil and the United States. Agricultural Trade Liberalization: Policy and Implications for Latin America, 295-331.

Becker, K. M., Parsons, R. L., Kolodinsky, J., \& Matiru, G. N. (2007). A cost and returns evaluation of alternative dairy products to determine capital investment and operational feasibility of a small-scale dairy processing facility1. Journal of Dairy Science, 90(5), 2506-2516. https://doi.org/10.3168/jds.2006-433.

Belloin, J. C. (1988). Milk and dairy products: Production and processing costs. FAO animal production and health paper 62. Rome: Food and Agriculture Organization of the United Nations.

Ben-Ner, A. (1988). The life cycle of worker-owned firms in market economies. Journal of Economic Behavior \& Organization, 10(3), 287-313. https://doi.org/10.1016/0167. 2681(88)90052-2.

Boysen, O., \& Schröder, C. (2005). Economies of Scale in der Produktion versus Diseconomies im Transport: zum Strukturwandel in der Milchindustrie. Diskussionsbeiträge des Fachbereichs Wirtschaftswissenschaft der Freien Universität Berlin Volkswirtschaftliche Reihe. 2005Berlin: Freie Univ15.

BRASIL (2017). Censo Das Cooperativas Do Leite, 2015 - Síntese Dos Resultados. http:// www.somoscooperativismo.coop.br/leite/resultado.html.

Carvalho, V. R. F. (2012). Indústria de Laticínios No Rio Grande Do Sul: Um Panorama Após o Movimento de Fusões e Aquisições. http://cdn.fee.tche.br/eeg/1/mesa_10_carvalho, pdf.

Carvalho, V. R. F. (2008). Tese - Reestruturação Do Sistema Lácteo Mundial: Uma Análise Da Inserção Brasileira. UNIVERSIDADE ESTADUAL DE CAMPINAS Instituto de Economia.

Chaddad (2007a). The evolution of Brazilian dairy cooperatives: A life cycle approach. XLV Congresso Da Sober, Conhecimentos Para Agricultura Do Futuro (pp. 22-25). http://www.sober.org.br/palestra/6/335.pdf.

Chaddad (2007b). Cooperativas No Agronegócio Do Leite: Mudanças Organizacionais e Estratégicas Em Resposta à Globalização. Organizações Rurais \& Agroindustriais, 9(1), 69-78.

Chaddad, F. R., \& Cook, M. L. (2004). Understanding new cooperative models: An ownership-control rights typology. Applied Economic Perspectives and Policy, 26(3), 348-360. https://doi.org/10.1111/j.1467-9353.2004.00184.x.

Chaddad, F., \& Iliopoulos, C. (2013). Control rights, governance, and the costs of ownership in agricultural cooperatives: Control rights, governance, and the costs of ownership. Agribusiness, 29(1), 3-22. https://doi.org/10.1002/agr.21328.

Chaddad, F. R., \& Jank, M. S. (2006). The evolution of agricultural policies and agribusiness development in Brazil. Choices, 21(2), 85-90.

Cook, M. L. (1995). The future of U.S. agricultural cooperatives: A neo-institutional approach. American Journal of Agricultural Economics, 77(5), 1153-1159. https://doi. org $/ 10.2307 / 1243338$.

Cook, M. L., \& Burress, M. J. (2009). A cooperative life cycle framework. Unpublished ManuscriptColumbia, Mo: University of Missouri Dept. of Agricultural Economics. https://www.researchgate.net/profile/Michael_Cook4/publication/228545021_A_ Cooperative Life Cycle Framework/links/09e13caece40000000.pdf.

Cook, M. L., \& Iliopoulos, C. (1998). In G. W. Ziggers, J. H. Trienekens, \& P. J. P. Zuurbier (Eds.). Solutions to property rights constraints in producer-owned and controlled organizations: Prerequisite for agri-chain leadership? (pp. 541-553). Wageningen, the 
Netherlands: Wageningen Agricultural University.

Cook, M. L., \& Iliopoulos, C. (2016). Generic solutions to coordination and organizational costs: Informing cooperative longevity. Journal on Chain and Network Science, 16(1), 19-27. https://doi.org/10.3920/JCNS2016.x001.

Dalton, T. J., Criner, G. K., \& Halloran, J. (2002). Fluid milk processing costs: Current state and comparisons1. Journal of Dairy Science, 85(4), 984-991. https://doi.org/10. 3168/jds.S0022-0302(02)74158-1.

David, A., \& Garcia, L. A. F. (2009). Competitividade Das Cooperativas Do Sistema de Cooperativas de Leite Da Agricultura Familiar-SISCLAF. INFOCOS-Instituto de Formação Do397.

de Souza, J. J.é (2009). Gênese e Evolução Da Indústria de Laticínios Do Oeste de Santa Catarina. http://repositorio.ufsc.br/handle/123456789/93207.

de Souza, J. J.é (2014). O Complexo Agroindustrial de Laticínios No Brasil. Thesis, Florianópolis/SC: UNIVERSIDADE FEDERAL DE SANTA CATARINA.

de Souza, R. P. (2007). As Transformações Na Cadeia Produtiva Do Leite e a Viabilidade Da Agricultura Familiar: O Caso Do Sistema COORLAC (RS)Master Thesis. Porto Alegre: Universidade Federal do Rio Grande do Sul.

Deng, W., \& Hendrikse, G. (2014). Cooperative social capital-towards a lifecycle perspective August 26-29, 2014, Ljubljana, Slovenia. European Association of Agricultural Economists. 2014 International Congress. http://ageconsearch.umn.edu/ bitstream/182922/2/Cooperative_Social_Capital__-_Towards_a_Lifecycle Perspective_-_EAAE-2014-Final.pdf.

Deves, O.ávioD., Rambo, A. G., \& Lovois de, A. M. (2008). A Mesorregião Grande Fronteira Do Mercosul: Uma Análise Dos Sistemas Agrários e Das Políticas de Desenvolvimento Neste 'Território'. Anais Do Evento, 4Porto Alegre, RS: EDIPUCRShttp://hdl.handle.net/ $10183 / 30350$.

Donaldson, L. (2001). The contingency theory of organizations. Foundations for organizational science. SAGE Publicationshttps://books.google.de/books?id=hXroN8btsN8C.

Escher, F. (2011a). Os Assaltos Do Moinho SatâNico Nos Campos e Os Contramovimentos Da Agricultura Familiar.

Escher, F. (2011b). A Evolução Institucional Do Sistema de Cooperativas de Leite Da Agricultura Familiar Com Interação Solidária-SISCLAF: Atores Sociais, Mercados e Ação Coletiva No Sudoeste Do Paraná. http://www.ufrgs.br/pgdr/eventos/2011/III Coloquio/arquivos oficinas/Escher.pdf.

Ferrari, D., Luiz, Márcio, Antonio, M., Marcos Testa, V., \& Luiz Silvestro, M. (2005). Agricultores Familiares, Exclusão e Desafios Para Inserção Econômica Na Produção de Leite Em Santa Catarina. Informações Econômicas, São Paulo, 35(1), 22-36.

Francesconi, G. N., \& Ruben, R. (2008). The life cycle of agricultural Co-operatives: Implications for management and governance in Ethiopia. Journal of Rural Cooperation, 36(2), 115-130.

Frenken, K. (2014). The evolution of the Dutch dairy industry and the rise of cooperatives: A research note. Journal of Institutional Economics, 10(01), 163-174.

Grosskopf, W., Münkner, H.-H., \& Ringle, Günther (2010). Our Co-Op: Idea - mission achievements. Neu-Ulm: DG-Verl.

Hendrikse, G., \& Feng, L. (2013). Interfirm cooperatives. Chapters.

Hoff, K., \& Stiglitz, J. E. (1990). Introduction: Imperfect information and rural credit markets: Puzzles and policy perspectives. The World Bank Economic Review, 4(3), 235-250.

IBGE (1996). IBGE :: Instituto Brasileiro de Geografia e Estatística. Censo Agropecuário 1996. http://www.ibge.gov.br/home/.

IBGE (2006). IBGE :: Instituto Brasileiro de Geografia e Estatística. Censo Agropecuário 2006. http://www.ibge.gov.br/home/.

IBGE (2014). IBGE:: Instituto Brasileiro de Geografia e Estatística. 2014. http://www.ibge. gov.br/home/.

IBGEIBGE . (2017). Instituto Brasileiro de Geografia e Estatística. 2017http://www.ibge. gov.br/home/.

Iliopoulos, C., \& Cook, M. L. (2013). Property rights constraints in producer-owned firms: Solutions as prerequisites for successful collective entrepreneurship. https://emnet.univie. ac.at/uploads/media/Cook_Iliopoulos.pdf.

Jank, M. S., Farina, E., \& Galan, V. B. (1999). O Agribusiness Do Leite No Brasil. Milkbizz/ PENSA.

Johnson, G., Whittington, R., Angwin, D., Regner, P., \& Scholes, K. (2014). Exploring strategy: Text and cases (10th edition). Harlow, England: Pearson Education Limited. https://www.dawsonera.com/guard/protected/dawson.jsp?name $=$ https://login northumbria.ac.uk/idp/shibboleth\&dest = http://www.dawsonera.com/depp/ reader/protected/external/AbstractView/S9781292006895.

Magalhães, R. S. (2007). Habilidades Sociais No Mercado de Leite. RAE-Revista de Administração de Empresas, 47(2), 15-25.

Martins, P. C., Álvares, J. G., Barros, G. S. C., Nogueira Netto, V., \& Barroso, M. (2004). O Futuro Do Cooperativismo de Leite. Embrapa Gado de Leite.

Mayring, P. (2014). Qualitative content analysis. Theoretical foundation, basic procedures and software solution. Klagenfurt. http://nbn-resolving.de/urn:nbn:de:0168-ssoar-395173.

Medeiros, M. C., \& Padilha, W. (2015). Os Ciclos de Desenvolvimento Do Cooperativismo Agropecuário e o Crédito Rural No Sudoeste Do Paraná. Geosul, 29(58), 185-205.

MESOMERCOSUL (2007). MESOMERCOSUL. 2007http://www.mesomercosul.org.br/.

Mosheim, R., \& Lovell, C. A. K. (2009). Scale economies and inefficiency of US dairy farms. American Journal of Agricultural Economics, 91(3), 777-794.

OCB (2012). OCB - Organização Das Cooperativas Do Brasil, Relatório Anual 2012.

OECD (2015). Dairy. In OECD, \& FAO (Eds.). OECD-FAO agricultural outlook 2015OECD Publishinghttps://doi.org/10.1787/agr_outlook-2015-11-en.

Ortmann, G. F., \& King, R. P. (2007). Agricultural cooperatives I: History, theory and problems. Agrekon, 46(1), 18-46.

Pérotin, V. (2006). Entry, exit, and the business cycle: Are cooperatives different? Ukrainian Labor Market in Transition, 34(2), 295-316. https://doi.org/10.1016/j.jce. 2006.03.002.

Rangasamy, N., \& Dhaka, J. P. (2007). Milk procurement cost for Co-operative and private dairy plants in Tamil Nadu-A comparison. Indian Journal of Agricultural Economics, 62(4), 679.

Rebelo, J., \& Caldas, J. (2015). The economic role of the Portuguese agricultural cooperatives. Revista de Economia e Sociologia Rural, 53(March), 91-102. https://doi org/10.1590/1234-56781806-94790053s01007.

Schubert, M. N. \& Niederle, P. A.é (2011). A Competitividade Do Cooperativismo de Pequeno Porte No Sistema Agroindustrial Do Leite No Oeste Catarinense. Revista IDeAS, 5(1), 188-216.

Souza, R. P., \& Waquil, P. D. (2008). A Viabilidade Da Agricultura Familiar Produtora de Leite: $O$ Caso Do Sistema COORLAC (RS). Sociedade Brasileira de Economia, Administração e Sociologia Rural. Congresso (46.: 2008, 20-23 Jul.: Rio Branco).[Anais Do Congresso Da] SOBER [Recurso Eletrônico]. Rio Branco: Sober, 2008http://www. lume.ufrgs.br/bitstream/handle/10183/31553/000685074.pdf?sequence $=1$.

Staber, U. (1993). Worker cooperatives and the business cycle: Are cooperatives the answer to unemployment? American Journal of Economics and Sociology, 52(2), 129-143.

Terfloth, K. (2015). Co-operative life cycle theory. Consumers cooperative of Berkeley, CA.

Theuvsen, L., \& Franz, A. (2007). The role and success factors of livestock trading cooperatives: Lessons from German pork production. International Food and Agribusiness Management Review, 10(3), 90-112.

Whitman, J. (2011). The worker cooperative life cycle. Prepared for the Babson-Equal Exchange Cooperative Curriculum.

Wouterse, F., \& Francesconi, G. N. (2016). Organisational health and performance: An empirical assessment of smallholder producer organisations in Africa. Journal on Chain and Network Science, 16(1), 29-40. https://doi.org/10.3920/JCNS2016.x002. 